\title{
Research on Properties of Composites Based on Magnesium Binders
}

\author{
Elvija Namsone \\ Riga Technical university \\ Faculty of Civil Engineering \\ Institute of Materials and Structures \\ Riga, Latvia \\ elvija.namsone@inbox.lv \\ Eva Namsone \\ Riga Technical university \\ Faculty of Civil Engineering \\ Institute of Materials and Structures \\ Riga, Latvia \\ eva.namsone@inbox.lv
}

\author{
Genadijs Sahmenko \\ Riga Technical university \\ Faculty of Civil Engineering \\ Institute of Materials and Structures \\ Riga, Latvia \\ genadijs.sahmenko@rtu.lv \\ Aleksandrs Korjakins \\ Riga Technical university \\ Faculty of Civil Engineering \\ Institute of Materials and Structures \\ Riga, Latvia \\ aleksandrs.korjakins@rtu.lv
}

\author{
Endija Namsone \\ Riga Technical university \\ Faculty of Civil Engineering \\ Institute of Materials and Structures \\ Riga, Latvia \\ endija.namsone@inbox.lv
}

\begin{abstract}
- the research is devoted to composites based on magnesium binders, which is very perspective building material in the modern construction industry. Magnesium based binders have better compatibility with organic fillers comparing to traditionally lime binder cement [1]. In this investigation two magnesium-based binders are used, such as magnesium chloride and magnesium sulphate. The aim of this study is to investigate the physical, mechanical and durability properties of composites based on magnesium binders, such as density, compressive strength, thermal conductivity and capillary water absorption, and to obtain magnesium binder that could be used to produce foamed concrete. This can be done by improving the composition of the mixture. In this framework properties of magnesium binders are analysed and how these binders can affect to the properties of magnesium based composites.
\end{abstract}

Keywords-magnesium binders, magnesium oxychloride and sulphate cement.

\section{INTRODUCTION}

Since the building domain has obsessed a significant role of the energy consumption in recent years, the demand for efficient construction has become more important. Nowadays the building sector in regular covers up to $40 \%$ of all energy. A lot of industrial activities, factories and also building cause environmental pollution and $\mathrm{CO}_{2}$ emission. High level of these emissions caused by manufacturing of building materials and low energy of buildings are the main reasons for promoting the greenhouse gas. On this account increasingly is paid attention to environmentally friendly construction materials that accomplish requirements of high-level energy efficiency [2].

The European Union has announced several public documents and guidance for the purpose of reducing pollution and $\mathrm{CO} 2$ emissions, for example the Paris Agreement in 2016 [3]. The main objective of the directive EU2010/31/EU is to limit the amount of emissions by 20
$\%$ till 2020 [4] and of the Energy and Climate framework 2030 by $40 \%$ till 2030 [5].

In addition, besides the most significant environmental inflecting factor the Global Warming Potential, there are other factors that should be considered - toxicity, acidulation etc. Manufacturing of building materials affects the environmental a lot because of multitude amount use of raw materials and energy intensity [3] [5] [4]. Therefore there is a need for additional efforts to reach all objectives. So even more all new buildings are required to become as nearly zero-energy [6]. Thereby buildings have high energy performance and use of renewable energy sources. [7]

It is also important to note that one of more widely used building materials all over the world is cement. Despite the good qualities of it, there are a lot of undesirable consequences. It must be understood that cement accounts up to $94 \%$ of $\mathrm{CO}_{2}$ emissions and the main of energy consuming processes is directly the production. [8]

Thereby there is consumed a lot of raw materials and there is a need to find a way to reduce energy consumption. One of the solutions could be the use of magnesium binding materials. [9]

Due to the low calcination temperature the magnesium based cements can bring environmental benefits. So there are different types of $\mathrm{MgO}$ based cements and the most typical are - Magnesium Phosphate cements, Magnesium Silicate cements, Magnesium Oxychloride cements and Magnesium Oxysulphate cements. Magnesium based cements are suited for prefabricated construction, roadwork and other fields. These cements would rather use $\mathrm{MgO}$ then $\mathrm{CaO}$ (involves more than $60 \%$ of Portland cement). Whereas the chemical compositions of these two are very different, it is not so simply to change the raw material for Ca-based cements. [10][11]

Print ISSN 1691-5402

Online ISSN 2256-070X

http://dx.doi.org/10.17770/etr2019vol1.4157

(C) 2019 Elvija Namsone, Genadijs Sahmenko, Endija Namsone, Eva Namsone, Aleksandrs Korjakins. Published by Rezekne Academy of Technologies.

This is an open access article under the Creative Commons Attribution 4.0 International License. 


\section{A. Magnesium Oxy-Chloride cement}

Magnesium Oxy-Chloride cements is indicated by $\mathrm{MOC}$ and relies on water reaction between $\mathrm{MgO}$ and $\mathrm{MgCl} 2$. So the chemical formula of raw materials is $\mathrm{MgO}+\mathrm{MgCl} 2$ [12]. It is also known as Sorel cement, as it was first announced by Sorel in 1866. Sorel cement is characterized by high strength, bonding and quick setting, also it is hard, fire proof so it could be used for heavy floorings because of relatively light weight [13] [11].

Despite that MOC binders have been used less for flooring in the last decade because of doubt about sensitivity to water damage and also high costs. But the topic about fire resistance is getting more actual, as there is another interest about uses. That's way there is another application nowadays - production of boards containing wood fibres and perlite, overlayed by glass cloth. These boards have look of chipboard and ability to withstand nails and screws. Since there are used $\mathrm{MgO}$ and a low temperature during production, almost always they are indicated as "eco" products or carbon-neutral. [11] [14]

The compressive strength is about $120-140 \mathrm{MPa}$. The coefficient of thermal expansion is low and chemical formulas for compounds are $3 \mathrm{Mg}(\mathrm{OH})_{2} \cdot \mathrm{MgCl}_{2} \cdot 8 \mathrm{H}_{2} \mathrm{O}$ (phase three) and $5 \mathrm{Mg}(\mathrm{OH})_{2} \cdot \mathrm{MgCl}_{2} \cdot 8 \mathrm{H}_{2} \mathrm{O}$ (phase five) [12]. Normally it is assumed for cements to calcinate magnesium at $800-1000{ }^{\circ} \mathrm{C}$, but the temperature of calcination is about $700^{\circ} \mathrm{C}[11]$. At higher temperatures of calcination releases a less reactive $\mathrm{MgO}$ or dead burned. Whereas $\mathrm{MgO}$ reacts with $\mathrm{MgCl}$, so it is unable for $\mathrm{CO}_{2}$ to be absorbed through carbonation and because of this the less $\mathrm{CO}_{2}$ is created [15].

\section{B. Magnesium Oxy-Sulfate cements}

Magnesium Oxy-Sulphate cements are indicated by MOS and in general are similar to MOC, but the main difference is that $\mathrm{MgSO}_{4}$ is used instead of $\mathrm{MgCl}_{2}$ [11]. The chemical formula of raw materials $\mathrm{MgO}+\mathrm{MgSO}_{4}$, but for compounds $-3 \mathrm{Mg}(\mathrm{OH})_{2} \cdot 3 \mathrm{MgSO}_{4}$ (phase three) and $5 \mathrm{Mg}(\mathrm{OH})_{2} \cdot \mathrm{MgSO}_{4} \cdot 2 \mathrm{H}_{2} \mathrm{O}$ (phase five) [12].

These types of cements obtained interest thanks to that magnesium sulphate is less hygroscopic than magnesium chloride. And it was proven to have better resistance to atmospheric effects. However, magnesium oxysulphate cements have fewer applications and available literature is limited comparing to MOC cements. Owing to the limited solubility of $\mathrm{MgSO}_{4} \cdot 7 \mathrm{H}_{2} \mathrm{O}$ (at room temperature), it is more complicated to form MOS cements. [11] [16] [17]

The main application of magnesium oxysulphate cement is production of lightweight insulating panels that contain impregnative wood shavings. There is an option to produce several types of panels with different uses and they are suitable for construction, public and residential buildings etc. [10]

\section{MATERIALS AND METHODS}

\section{A. Used materials}

All magnesium - based binders were obtained experimentally in a laboratory setting using the main components as follows:

Magnesium oxide - in this research caustic magnesia as main binding agent was used, being made by calcination of magnesite $\left(\mathrm{MgCO}_{3}\right)$. The used magnesium oxide is produced by "RHI AG Ltd", Austria. The properties of the material are as follows: $73.0 \% \mathrm{MgO}, 4.0 \% \mathrm{CaO}, 4.0 \%$ $\mathrm{SiO}_{2}, 3.0 \% \mathrm{Fe}_{2} \mathrm{O}_{3}, 1.0 \% \mathrm{Al}_{2} \mathrm{O}_{3}$, size distribution $90 \%<30$ $\mu \mathrm{m}$ and calcination temperature $750^{\circ}$.

Magnesium chloride hexahydrate, produced in Germany and containing $47 \% \mathrm{MgCl}_{2}$ was used as brine solution (with proportions 1:1 salt: water by weight) and also magnesium sulphate was used as brine solution (with proportions 1:1 salt: water by weight) to produce mixtures.

Natural, washed sand was used as a filling component. Sand with fraction size $0-1.0 \mathrm{~mm}$ and supplied by "Sakret", Latvia was used.

Pozzolanic additives - microsilica (MS) or silica fume was used. MS with fine particles $(1 \mu \mathrm{m}-15 \mathrm{~nm})$ works as the supplementary cementing material [18] and improves the water resistance of binding material [19].

\section{B. Mixtures}

In this experimental study mixtures with $\mathrm{MgO} / \mathrm{sand}$ ratio 0.5 were produced, the amount of $\mathrm{MgCl}_{2}, \mathrm{MgSO}_{4}$, metakaolin (MK) and MS was variable (see data in table 1). Experimental mixes 1-6 were produced using $\mathrm{MgCl}_{2}$ and three of these mixes (4-6) were produced adding MS additive. Using $\mathrm{MgSO}_{4}$, the compositions A-F were made. Three of these compositions (D-F) were also produced by adding MS.

In this experimental study, foam concrete compositions were also prepared without adding sand. These mixes were made by pre-foaming technology where magnesiumbased binder was mixed with beforehand prepared foam (synthetic foaming agent PB-Lux was used). The ratio of monopotassium phosphate and $\mathrm{MgO} 0.8$ and $\mathrm{MgCl}_{2} / \mathrm{MgO}$ 0.67 was used.

TABLE I. MIXES OF MAGNESIUM BINDER

\begin{tabular}{|c|c|c|c|c|c|c|c|c|}
\hline \multirow{2}{*}{$\begin{array}{c}\text { Designations } \\
\text { of mixes }\end{array}$} & \multicolumn{6}{|c|}{ Ingredients (weight proportions of the $\mathrm{MgO}$ ) } \\
\cline { 2 - 9 } & $\begin{array}{c}\text { Sand 0-1 } \\
\mathrm{mm}\end{array}$ & $\mathrm{MgO}^{2}$ & $\mathrm{MgCl}_{2}$ & $\mathrm{MS}$ & Water & $\mathrm{MgSO}_{4}$ & $\mathrm{~K}_{2} \mathrm{PO}_{4}$ & PB-Lux \\
\hline 1 & 2 & 1 & 0.67 & 0 & 0 & 0 & 0 & 0 \\
\hline 2 & 2 & 1 & 0.5 & 0 & 0.17 & 0 & 0 & 0 \\
\hline 3 & 2 & 1 & 0.33 & 0 & 0.33 & 0 & 0 & 0 \\
\hline 4 & 2 & 1 & 0.67 & 0.07 & 0 & 0 & 0 & 0 \\
\hline 5 & 2 & 1 & 0.5 & 0.07 & 0.17 & 0 & 0 & 0 \\
\hline 6 & 2 & 1 & 0.33 & 0.07 & 0.33 & 0 & 0 & 0 \\
\hline A & 2 & 1 & 0 & 0 & 0 & 0.67 & 0 & 0 \\
\hline B & 2 & 1 & 0 & 0 & 0.17 & 0.5 & 0 & 0 \\
\hline C & 2 & 1 & 0 & 0 & 0.33 & 0.33 & 0 & 0 \\
\hline D & 2 & 1 & 0 & 0.07 & 0 & 0.67 & 0 & 0 \\
\hline E & 2 & 1 & 0 & 0.07 & 0.17 & 0.5 & 0 & 0 \\
\hline F & 2 & 1 & 0 & 0.07 & 0.33 & 0.33 & 0 & 0 \\
\hline I & 0 & 1 & 0 & 0 & 0.55 & 0 & 0.80 & 0.80 \\
\hline II & 0 & 1 & 0.67 & 0 & 0.10 & 0 & 0.13 & 0.80 \\
\hline
\end{tabular}




\section{Testing methods}

The test of compressive strength was performed using semi-automatic testing machine "CONTROLS". The force was applied with a constant speed $(0.05 \mathrm{MPa} / \mathrm{s})$. Samples (six pieces of each series) with dimensions $50 \times 50 \times 50 \mathrm{~mm}$ were subjected to the test and were stored at the temperature $15-20^{\circ} \mathrm{C}$ and relative humidity level $\sim 90-95 \%$. The parameters of compressive strength were determined both in dry and wet condition of the magnesium-based samples, so the softening coefficient was determined (1):

$$
\mathrm{K}=\frac{\mathrm{R}_{\mathrm{wet}}}{\mathrm{R}_{\mathrm{dry}}}, w \text { ere }
$$

$\mathrm{R}_{\text {wet }}$ - compressive strength of specimen cured in water during the hardening, $\mathrm{MPa}$;

$\mathrm{R}_{\text {dry }}$ - compressive strength of dry specimen, $\mathrm{MPa}(\mathrm{RH}$ $90-95 \%$, temp. $15-20^{\circ} \mathrm{C}$ ).

According to the methodology of the standard LVS EN 722-11 the test of capillary water absorption was performed. Specimens were immersed in water in the depth of $5 \mathrm{~mm}$. To keep the water level even across the entire cross-section of the sample, the spacers under the specimens were used (see Fig.1).

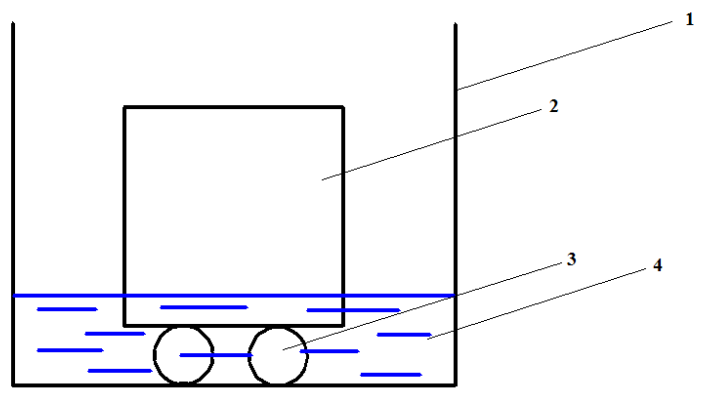

Fig. 1. Scheme of capillary water absorption test, where: $1-$ container, 2 - testing specimen, 3 - spacers, 4 - water level.

During the test masses of the samples were periodically controlled and determined after 10, 15, 20, 30 minutes and 1,24 , hours (from the beginning of this test).

The coefficient of capillary water absorption $\mathrm{C}$ was calculated by (2):

$$
\mathrm{C}=\frac{\mathrm{m}_{\mathrm{s}} \mathrm{m}_{\mathrm{d}}}{\mathrm{A}_{\mathrm{s}}}, w \text { ere }
$$

- mass of the specimen after the process of water soaking (g);

- mass of the specimen after the process of drying (g);

- cross area of the specimen surface immersed in water $\left(\mathrm{dm}^{2}\right)$.

According to standard EN 12667 guidelines, test of thermal conductivity was performed. For determination of the coefficient of thermal conductivity, heat flow measurement device 'Laser Comp's heat flow meter instrument FOX 600`was used.

The Bio-Fourier law, where the heat flow, the coefficient of thermal conductivity and temperature gradient are combined (3), is the main operating principle of the measuring equipment:

$$
q=\lambda\left(\frac{d T}{d x}\right), \text { where: }
$$

where:

$\mathrm{q}$ - heat flow through the sample $\left(\mathrm{W} / \mathrm{m}^{2}\right)$;

$\lambda$ - the coefficient of thermal conductivity $(\mathrm{W} / \mathrm{mK})$;

$\left(\frac{d T}{d x}\right)$ temperature gradient of flat surface $(\mathrm{K} / \mathrm{m})$ [20]

The thermal conductivity test was performed on samples that were produced by pre-foaming mixing technology. Magnesium-based specimens - plates with dimensions of $315 \times 320 \times 31.30 \mathrm{~mm}$ and $305 \times 305 \times 43.80$ $\mathrm{mm}$ (the thickness was determined by heat flow meter; accuracy $0.01 \mathrm{~mm}$ ) were used during the test. The settings of the test were as follows: $0^{\circ} \mathrm{C}$ at the upper (cold part) and $20^{\circ} \mathrm{C}$ at the lower metal plate (warm part), making temperature difference of $20^{\circ} \mathrm{C}$.

The water/binder ratio was calculated:

$$
\text { water/binder }=\frac{0.5 \mathrm{MgCl}+\mathrm{H}_{2} \mathrm{O}}{\mathrm{MgO}+\mathrm{MS}+0.5 \mathrm{MgCl}} \text {, where }
$$

$\mathrm{MgCl}$ - amount of magnesium chloride ( $\mathrm{kg})$;

$\mathrm{MgO}$ - amount of magnesium oxide $(\mathrm{kg})$;

$\mathrm{H}_{2} \mathrm{O}$ - amount of water $(l)$;

MS - amount of microsilica $(\mathrm{kg})$;

\section{RESULTS AND DISCUSSION}

\section{A. Density and compressive strength}

The data on the density and compressive strength (7 days) from produced magnesium chloride (1-6) and magnesium sulphate (A-F) binder mixes are summarized in the graph (see Fig.2).

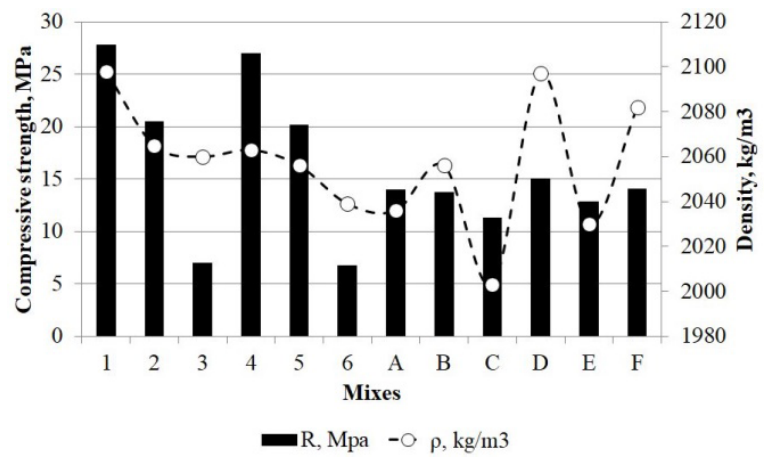

Fig. 2. Results obtained from the density and compressive strength ( 7 days).

Results show that using higher amount of magnesium chloride increases compressive strength 1.9 times comparing to adequate amount of magnesium sulphate. The opposite view are with data of $50 \%$ of magnesium chloride amount that shows $62 \%$ lower value of compressive strength comparing results to adequate amount of magnesium sulphate.

It also can be concluded that decreasing ratio of magnesium chloride decreases value of compressive strength 
from 27.8 $\mathrm{MPa}$ to $7 \mathrm{MPa}$. Similar tendency have mixes with magnesium sulphate - decreasing ratio of magnesium sulphate decreases value of compressive strength from $14 \mathrm{MPa}$ to $11.3 \mathrm{MPa}$.

\section{B. Capillary water absorption}

The data on the capillary properties obtained from produced magnesium chloride binder (see Fig. $3 \mathrm{~A}$ ) and magnesium sulphate binder (see Fig. 3 B) mixes are summarized in the graphs.

Obtained results show that decreasing magnesium chloride up to two times increases capillary water absorption from $30 \mathrm{~g} / \mathrm{dm}^{2}$ in average to $75 \mathrm{~g} / \mathrm{dm}^{2}$ during the time of three hours.

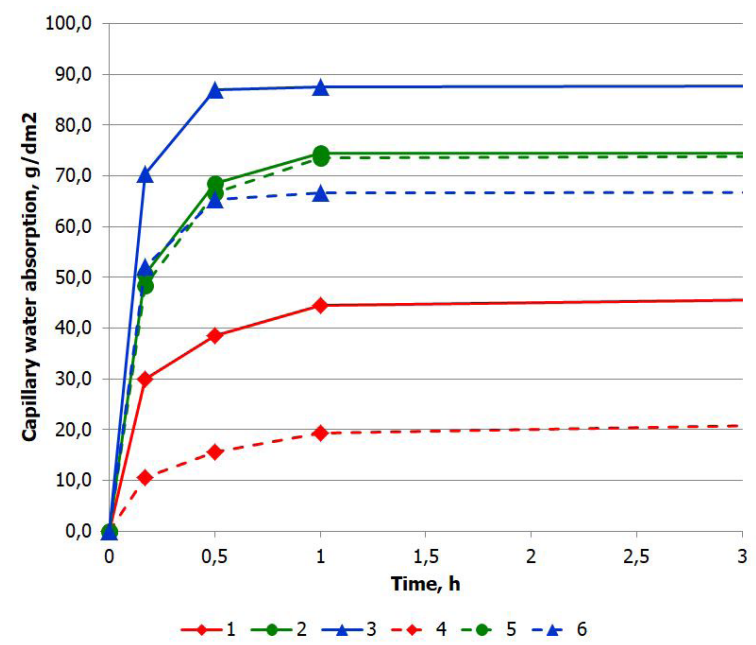

A

Fig. 3. Results obtained from the capillary absorption test (first 3 hours, designations of mixes 1-6 and mixes A-F see in table I).

\section{Coefficient of thermal conductivity}

The data on the thermal conductivity obtained from produced magnesium phosphate mixes (mixes with phosphate, magnesium oxide and foaming agent; mixes with phosphate, magnesium oxide, magnesium chloride and foaming agent (PBLux), see Table 1).

Results show that decreasing amount of water and monopotassium phosphate decreases value of coefficient of thermal conductivity from $0.101 \mathrm{~W} / \mathrm{mK}$ to $0.093 \mathrm{~W} / \mathrm{mK}$ (mixes I and II).

$C$. It also can be concluded that use of magnesium chloride decreases value of coefficient of thermal conductivity.

Water/binder-compressive strength

The data about water/binder ratio (4) and compressive strengthof7 days, agraphicrelationshipiscreated(seeFig.4).
It also can be concluded that role of using microsilica fume depends on used magnesium type - decreases capillary water absorption up to 2.3 times in magnesium chloride case (comparing to results of higher amount of $\mathrm{MgCl}_{2}$ and $75 \%$ of amount of $\mathrm{MgCl}_{2}$ ), while using magnesium sulphate doesn't affect such an important difference. Microsilica has fine particles $(1 \mu \mathrm{m}-15 \mathrm{~nm})$ and it ensures compact packing of used ingredients. It helps to increase water resistance of the specimens.

Results show that significant is used ratio (used weight) of magnesium chloride. For example, higher amount of magnesium chloride decreases capillary water absorption up to 6 times comparing to $50 \%$ of amount of magnesium chloride.

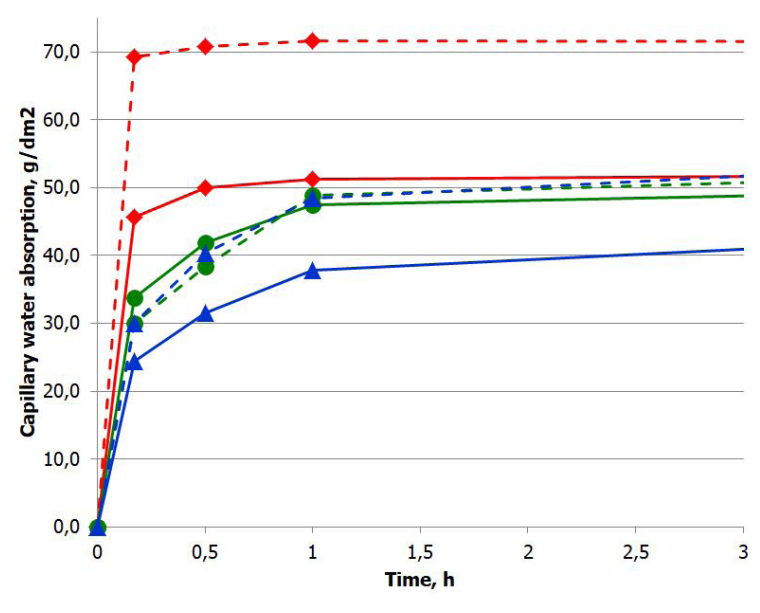

$\mathrm{B}$

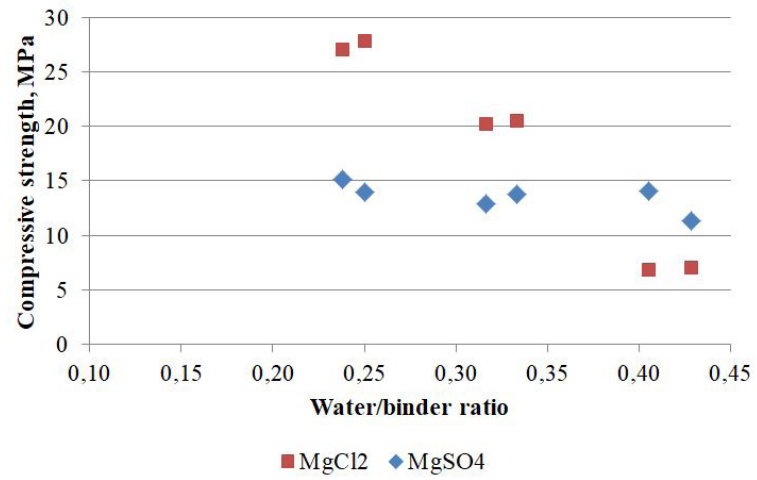

Fig. 4. Corelation between water/binder ratio and compressive strength.

Obtained results show that use of magnesium chloride obtains higher values of compressive strength from $38 \%$ up to $49 \%$ comparing to use of magnesium sulphate.

It also can be concluded that compressive strength depends on used water/binder ratio. Mixes with higher amount of magnesium binder are with lower values of water/binder ratio than mixes with $50 \%$ amount of magnesium binder.

In summarizing the data about magnesium binder amount and compressive strength of 7 days, a graphic relationship is created (see Fig.5). 


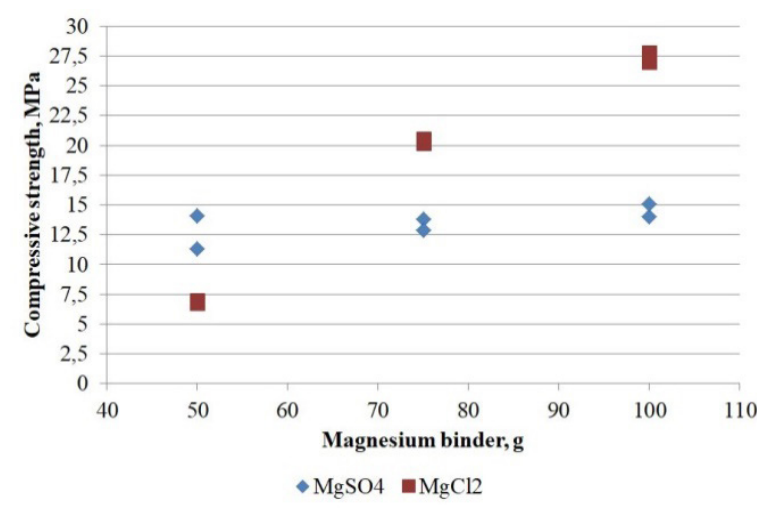

Fig. 5. Corelation between magnesium binder $(\mathrm{g})$ and compressive strength.

Obtained results show that graphic of compressive strength is ascending by using higher amount of magnesium chloride comparing to use of magnesium sulphate.

It also can be concluded that effectiveness of magnesium chloride decreases when $\mathrm{MgCl}_{2}: \mathrm{MgO}$ ratio is lower than 0.5 . Results show that use of $50 \%$ magnesium sulphate increases compressive strength from 6.9 $\mathrm{MPa}$ to 12.7 MPa.

\section{$D$.}

\section{Softening coefficient-compressive strength}

In summarizing the data about softening coefficient and compressive strength of 7 days, a graphic relationship is created (see Fig.6).

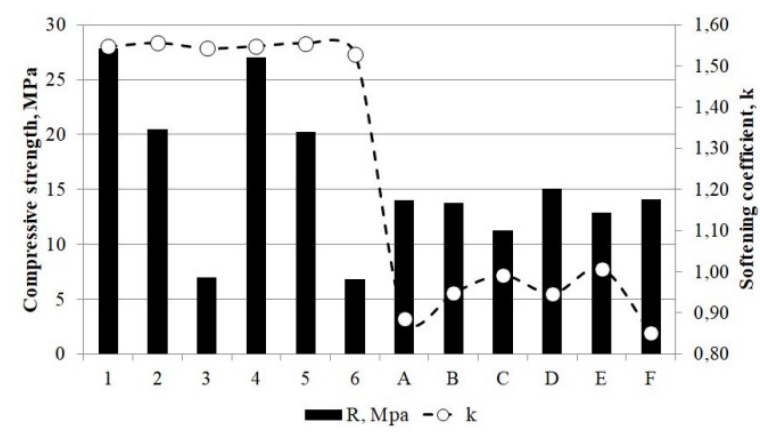

Fig. 6. Corelation between softening coefficient and compressive strength.

Obtained results show that compressive strength is ascending by using higher amount of magnesium binder type (chloride or sulphate).

IV. IT ALSO CAN BE CONCLUDED THAT VALUE OF SOFTENING COEFFICIENT IS HIGHER BY USING MAGNESIUM CHLORIDE

(IN RANGE 1.53 TO 1.56) COMPARING BY USING MAGNESIUM SULPHATE (IN RANGE 0.85 TO 1.01).

\section{Conclusions}

1. The use of $\mathrm{MgCl}_{2}$ allows achieving higher values of compression strength, comparing to the use of $\mathrm{MgSO}_{4}$ (approximately from $38 \%$ to $49 \%$ ).

2. The use of $\mathrm{MgCl}_{2}$ ensures about $56 \%$ lower values of capillary water absorption (comparing data of compositions with $100 \mathrm{~g}$ and $50 \mathrm{~g}$ of $\mathrm{MgCl}_{2}$ ).
3. Adding MS to mixes with $\mathrm{MgCl}_{2}$ reduces water absorption values, but for the compositions with $\mathrm{MgSO}_{4}$ it almost did not affected values of water absorption. The values of water absorption of $\mathrm{MgSO}_{4}$ mixes are $18 \%-68 \%$ lower comparing to compositions where $\mathrm{MgCl}_{2}$ was added.

4. The values of compressive strength of compositions with $\mathrm{MgSO}_{4}$ are not affected by water/binder ratio, but for the mixes where $\mathrm{MgCl}_{2}$ is added, the values of compressive strength decrease with increasing the water/binder ratio.

5. Decreasing amount of water and monopotassium phosphate ensures lower value of coefficient of thermal conductivity from $0.101 \mathrm{~W} / \mathrm{mK}$ to $0.093 \mathrm{~W} / \mathrm{mK}$ (mixes I and II).

The financial support of European Regional Development Fund PRoJeCt NR.1.1.1.1/16/A/007 „A NEW Concept for Sustainable and Nearly Zero-Energy BUILDINGS" IS ACKNOWLEDGED.

\section{REFERENCES}

[1] V. Vaganov, A. Kireev, S. Avdeev, G. Šahmenko, and M. Šinka, "Prospects for Effective Use of Dolomite in Concrete Compositions," Constr. Sci., vol. 19, pp. 27-32, Dec. 2018.

[2] E. Namsone, A. Korjakins, G. Sahmenko, and M. Sinka, "The environmental impacts of foamed concrete production and exploitation", Mater. Sci. Eng., vol. 251, pp. 20-29, 2017.

[3] United Nations, "Framework convention on climate change 2015 adoption of the Paris agreement", December, pp. 1-32, 2015. [Online]. Available: https://unfccc.int/resource/docs/2015/ cop21/eng/109r01.pdf [Accessed December, 2015].

[4] European Union, Directive 2010/31/EU of the European Parliament and of the Council of 19 May 2010 on the Energy Performance of Buildings, May 19, 2010. [Online]. Available: https://eur-lex.europa.eu/LexUriServ/LexUriServ.do?uri=OJ:L:2010:153:0013:0035:en:PDF [Accessed May 19, 2010].

[5] European Union, Energy and Climate Framework 2030, European Council 23/24 October. 2014. [Online]. Available: https:// www.consilium.europa.eu/sl/policies/climate-change/2030-climate-and-energy-framework [Accessed October, 2014].

[6] S. V. Korniyenko, N. I. Vatin, and A. S. Gorshkov, "Thermophysical field testing of residential buildings made of autoclaved aerated concrete blocks", Mag. Civ. Eng., no. 4, pp. 10-25, 2016.

[7] A. I. Review, "Zero Energy Building Definitions and Policy Activity", September, 2018. [Onine]. Available: https://ipeec.org/ upload/publication_related_language/pdf/766.pdf [Accessed September, 2018].

[8] O. Junichiro, T. Kohko, and A. Keigo, "2010 Energy Intensity (Cement Sector)", pp. 1-12, 2014. [Online]. https://www.rite. or.jp/system/en/latestanalysis/pdf/E-Comparison EnergyIntensity2010cement.pdf [Accessed September 2, 2014].

[9] O. Miryuk, "Properties of magnesium composite materials based on technogenic raw materials", J. Eng. Appl. Sci., vol. 13, no. 2, pp. 545-558, 2018.

[10] M. Halaris and D. T. Zampetakis, "Minerals in Architectural Markets", November, 2000. [Online]. Available: https://www. agrra.com.ph/news-events/magnesite-cements-presentation-industrial-minerals-annual-forum-minerals-architectural [Accessed: November 1, 2000].

[11] S. A. Walling and J. L. Provis, "Magnesia-Based Cements : A Journey of 150 Years , and Cements for the Future ?", vol. 116, pp.4170-4204, 2016.

[12] N. Yang, H. Tran, A. Scott, R. Dhakal, M. Watson, and C. Shi, Properties of magnesium based cements: Creative Solutions In: The New Zealand Concrete Industry, October 12-14, Te Papa, Wellington, New Zealand, 2017.

[13] L. F. Kazanskaya and O. M. Smirnova, "Supersulphated cements with technogenic raw materials", Int. J. Civ. Eng. Technol., vol. 
9, no. 11, pp. 3006-3012, 2018.

[14] A. K. Misra and R. Mathur, "Magnesium oxychloride cement concrete", Bull. Mater. Sci.,vol. 30, no. 3, pp. 239-246, 2007.

[15] A. Pina, P. Ferrão, J. Fournier, B. Lacarrière, O. Le Corre, and A I. Andri, "Bio-based construction panels for low carbon development", Energ. Proc., vol. 147, pp. 220-226, 2018.

[16] R. Mathur and S. K. Sharma, "Magnesium oxysulphate cement: change in properties on admixing sodium bivarbonate as an additive", Jour. Chem., vol. 1, no. 3, pp. 620-630, 2008.

[17] F. Chen, "Study on Preparation and Properties of Modified Magnesium Oxysulfate Cements", Chem. Eng. Trans., vol. 62, pp. 973-978, 2017.
[18] U. Sharma, A. Khatri, and A. Kanoungo, "Use of micro-silica as additive to concrete-state of art”, Int. J. Civ. Eng. Res., vol. 5, no. 1, pp. 9-12, 2014.

[19] Y. V. Ustinova, A. E. Nasonova, T. P. Nikiforova, and V. V. Kozlov, "Magnesium binder with the micro-silica additive", Proc. Moscow State Univ. Civ. Eng., vol. 7, pp. 147-151, 2012. 